\title{
PENGARUH TERAPI MUSIK SUARA AIR MENGALIR DENGAN BRAINWAVE TERHADAP PENURUNAN TINGKAT DEPRESI PADA LANSIA DI RUMAH PELAYANAN SOSIAL LANJUT USIA WENING WARDOYO UNGARAN
}

\section{THE EFECTS OF WATER SOUND MUSIC THERAPY \\ WITH BRAINWAVE TO THE DECREASE OF DEPRESSION LEVELS IN ELDERLY IN THE HOUSE OF SOCIAL CARE FOR ELDERLY WENING WARDOYO UNGARAN}

\author{
Hubertus Agung Pambudi ${ }^{1}$, Christina Chintia Dewi ${ }^{2}$, Hesti Anggraeni ${ }^{3}$ \\ ${ }^{1}$ Dosen Komunitas Jiwa STIKes St.Elisabeth Semarang \\ ${ }^{2}$ Mahasiswa Prodi S1 Ilmu Keperawatan STIKes St.Elisabeth Semarang \\ ${ }^{3}$ Dokter Spesialis Jiwa RSJD Dr. Aminogondho Hutomo Propinsi Jawa Tengah
}

\begin{abstract}
ABSTRAK
Saat masa usia lanjut sering terjadi penurunan kondisi fisik/ biologis, kondisi psikologis, serta perubahan kondisi sosial dan ekonomi, yang akan berpengaruh pada seluruh aspek kehidupan termasuk kesehatannya. Depresi merupakan salah satu masalah kesehatan jiwa yang sering muncul pada lansia. Tujuan penelitian ini untuk mengetahui apakah ada pengaruh pemberian terapi musik suara air mengalir dengan brainwave terhadap tingkat depresi lansia di Rumah Pelayanan Sosial Lanjut Usia Wening Wardoyo Ungaran. Penelitian ini merupakan penelitian kuantitatif dengan desain pre-eksperimen design dengan menggunakan pendekatan one group pretest-postest design. Pengambilan sampel menggunakan total sampling dengan jumlah sampel 31 responden. Instrument yang digunakan dalam penelitian ini untuk menilai tingkat depresi lansia menggunakan kuesioner Geriatric Depression Scale (GDS). Penelitian ini dilakukan selama 3 hari pada pagi dan sore hari selama 15 menit. Penelitian ini menggunakan uji Marginal Homogeneity. Penelitian ini menunjukkan pengaruh yang signifikan dari uji Marginal Homogeneity yaitu $p$ value 0,003 yang artinya $p<0,05$. Ada Pengaruh pemberian Terapi Musik Suara Air Mengalir dengan Brainwave terhadap Penurunan Tingkat Depresi pada Lansia di Rumah Pelayanan Sosial Lanjut Usia Wening Wardoyo Ungaran.
\end{abstract}

Kata Kunci: Terapi Musik, Suara Air mengalir, Brainwave, Depresi

\section{ABSTRACT}

Old age often accompanied by the declines in physical / biological conditions, psychological conditions, and changes in social and economic conditions, which will affect all aspects of life as well as their health. Depression is a mental health problem that often arises in the elderly. The purpose of this study was to determine whether there was an effect 
Bali Medika Jurnal.

Vol 7 No 1, 2020: 125-137

ISSN : 2615-7047

DOI: https://doi.org/10.36376/bmj.v7i1

of providing music therapy with sound water flowing with brainwave on the level of elderly depression in Wening Wardoyo Ungaran Elderly Social Services House. This research is a quantitative study with a pre-experimental design design using a one group pretestposttest design approach. Sampling uses total sampling with a sample of 31 respondents. The instrument used in this study to assess the level of depression in the elderly is the Geriatric Depression Scale (GDS) questionnaire. This research was conducted for 3 days in the morning and evening for 15 minutes. This research uses Marginal Homogeneity test. This study shows a significant effect of the Marginal Homogeneity test, which is $p$ value 0.003 , which means $p<0.05$. There is an Effect of giving Music Therapy Sounds of Flowing Water with Brainwave to the Decreased Depression Level in the Elderly in Wening Wardoyo Ungaran Elderly Social Services Home.

Keywords: Music Therapy, The Sound of Water Running, Brainwave, Depression

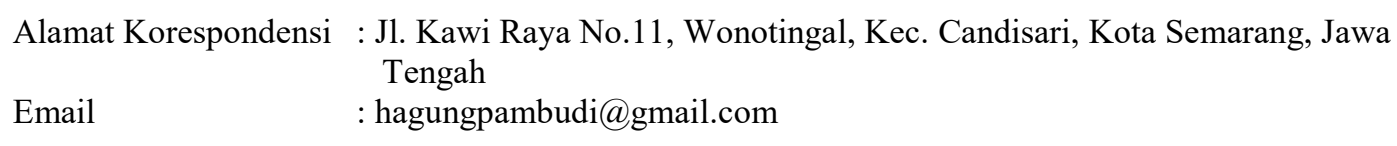

\section{PENDAHULUAN}

Lanjut usia menurut Peraturan Pemerintahan Republik Indonesia Nomor 43 tahun 2004, adalah seseorang yang telah mencapai usia 60 tahun keatas. Komposisi penduduk tua bertambah dengan pesat baik di negara maju maupun berkembang, hal ini disebabkan oleh penurunan angka fertilitas (kelahiran) dan mortilitas (kematian), serta peningkatan angka harapan hidup (life expectancy), yang mengubah struktur penduduk secara keseluruhan. Persentase terjadinya penuaan penduduk dipengaruhi oleh beberapa faktor yaitu, peningkatan gizi, sanitasi, pelayanan kesehatan, hingga kemajuan tingkat pendidikan dan sosial ekonomi yang semakin baik (Kemenkes RI, 2017).

Usia lanjut sering terjadi penurunan kondisi fisik/ biologis, kondisi psikologis, serta perubahan kondisi sosial dan ekonomi. Perubahan ini akan memberikan pengaruh pada seluruh aspek kehidupan termasuk kesehatannya. Pada proses menua sering menyebabkan lansia mengalami berbagai macam gangguan perasaan seperti sedih, cemas, kesepian, dan mudah tersinggung. Salah satu masalah kesehatan jiwa yang sering muncul pada lansia adalah masalah depresi, dimana depresi yang sering dialami lansia dipicu karena masalah keuangan, kesepian karena anak-anak tidak punya waktu untuk mengurus mereka dan masalah kesehatan yang semakin banyak dialami oleh lansia (Maryam \& Fatma, 2008; Namora, 2009).

Depresi adalah gangguan jiwa yang ditandai dengan sedih yang berkepanjangan, proses pikir melambat disertai penurunan motivasi dan perilaku lamban yang terkesan malas (trias depresi). Depresi bukan merupakan kelemahan atau kemalasan tetapi ketidakberdayaan pasien untuk mengatasi masalahnya. Kamus Collins mengartikan depresi sebagai keadaan mental dimana seseorang merasa murung dan tidak berdaya. Gangguan ini biasanya diawali dari stress yang tidak diatasi secara benar sehingga seseorang akan masuk ke fase depresi (Keliat et al., 2011). 
Depresi adalah ganguan mood, kondisi emosional berkepanjangan yang mewarnai seluruh proses mental (berpikir, perasaan, aktivitas) seseorang yang ditandai dengan pikiran negatif pada diri sendiri, suasana hati menurun, kehilangan minat atau motivasi, pikiran lambat serta aktivitas menurun (Keliat et al., 2011).

Data World Health Organization (WHO) tahun 2017 mengatakan tingkatan prevalensi depresi bervariasi berdasarkan usia, memuncak pada masa dewasa yang lebih tua yaitu, wanita yang berusia 55 sampai 74 tahun dengan persentase di atas $7,5 \%$ dan pada laki-laki dengan persentase 5,5\%. Secara global prevalensi dari gangguan depresi berdasarkan usia dan jenis kelamin, untuk usia 60 tahun atau lebih, dimana pada perempuan memiliki persentase sebesar $8 \%$ dan pada laki-laki sebesar 6,5\% (WHO, 2017).

Gangguan depresi dapat diatasi dengan menggunakan penanganan non farmakologi atau psikologis seperti, terapi interpersonal, konseling kelompok dan dukungan sosial, terapi humor, terapi kognitif dan terapi relaksasi seperti terapi musik. Penanganan depresi juga bisa dengan pola hidup seperti, berolahraga, mengatur pola makan, berdoa, memiliki keberanian untuk berubah, rekreasi. Penanganan depresi yang terakhir bisa menggunakan penanganan medis atau menggunakan farmakologi (Dirgayunita, 2016).

Penelitian dengan judul "Gambaran Tingkat Depresi Lansia yang Melakukan Senam di Panti Sosial Tresna Werdha di Jakarta" menuliskan bahwa berbagai perubahan psikologis mengakibatkan lansia sangat rentan mengalami berbagai penyakit fisik, selain itu perubahan psikososial yang terjadi pada masa tua akibat perubahan kognitif, kondisi penyakit, kehilangan peran sosial juga memengaruhi konsep diri lansia dan dapat menjadi stressor sehingga rentan mengalami masalah psikologis yang umum yaitu depresi, sehingga dapat disimpulkan dalam penelitian ini lansia yang rentan mengalami depresi adalah lansia yang kurang melakukan aktivitas fisik dimana aktivitas fisik dapat mendorong interaksi psikososial, meningkatkan harga diri, fungsi kognitif dan mencegah depresi (Putri \& Fitriyani, 2016).

Musik adalah bagian penting dari kehidupan sehari-hari, dimana musik sering dikaitkan dengan suasana hati. Dampak dari musik itu sendiri dapat mempengaruhi pola pikir dan kesejahteraan seseorang. Jenis musik berbeda-beda dalam jenis stimulus neurologis yang mereka bangkitkan, seperti musik klasik dimana musik ini dapat memberikan kenyamanan dan relaksasi pada seseorang (Dayat, 2018).

Penelitian dengan judul "Pengaruh Terapi Musik Klasik Terhadap Tingkat Depresi pada Lansia di Unit Rehabilitasi Sosial Wening Wardoyo Kecamatan Ungaran Kabupaten Semarang" menyatakan bahwa gelombang suara musik yang dihantarkan ke otak berupa energi listrik melalui jaringan syaraf yang akan membangkitkan gelombang otak yaitu gelombang alfa yang dapat membangkitkan relaksasi, gelombang beta terkait dengan aktivitas mental, gelombang theta terkait dengan situasi stres, depresi dan upaya kreativitas, sedangkan gelombang delta dikaitkan dengan situasi mengantuk. Sehingga dapat disimpulkan terapi musik klasik dapat menurunkan depresi pada lansia (Marzuki \& Lestari, 2018).

Suara alam adalah sebuah harmoni alamiah yang bisa menstimulus gelombang otak menjadi gelombang theta. Fase gelombang theta ini juga dapat muncul ketika seseorang memiliki perasaan dekat dengan Tuhan, sehingga dengan menstimulasi otak agar berada pada fase gelombang theta bisa menciptakan ketenangan jiwa. Hasil penelitian menyatakan musik suara alam dapat meningkatkan relaksasi, 
memperbaiki kondisi fisik, psikis bagi individu dengan berbagai usia (Wijayanti et al., 2016).

Observasi wawancara yang peneliti lakukan pada lansia yang tinggal di Rumah Pelayanan Sosial Lanjut Usia Wening Wardoyo Ungaran hampir seluruh lansia mengatakan dengan hal yang sama bahwa mereka selama tinggal di Rumah Pelayanan Sosial Lanjut Usia Wening Wardoyo Ungaran jarang bahkan tidak pernah dikunjungi oleh saudara maupun keluarga mereka sehingga menambah beban pikiran lansia. Selain itu penyebab depresi pada lansia adalah sering mengalami penyakit-penyakit yang membuat lansia cemas berlebihan dan akhirnya menjadi depresi, sehingga peneliti mencoba melakukan terapi non farmakologis dengan harapan lansia merasa nyaman dan tenang, sehingga membuat lansia sehat dan produktif sesuai dengan kemampuan lansia dan lansia bisa beraktifitas normal.

\section{METODE PENELITIAN}

Penelitian dilakukan di Rumah Pelayanan Sosial Lanjut Usia Wening Wardoyo Ungaran, waktu tanggal 25 Juli - 27 Juli 2019 pagi hari pada pukul 06:30 WIB dan sore hari pada pukul 16:00 WIB.

Penelitian ini menggunakan desain pre-eksperimen design dengan menggunakan pendekatan one group pretest-postest design. Tipe penelitian ini adalah mengungkapkan hubungan sebab akibat dengan cara melibatkan satu kelompok subjek. Pada design ini dilakukan observasi tingkat depresi sebelum (pretest) diberikan perlakuan terapi musik suara air mengalir dengan brainwave dan dilakukan observasi tingkat depresi kembali pada saat setelah (post-test) diberi perlakuan terapi musik suara air mengalir dengan brainwave untuk mendapatkan hasil yang lebih akurat karena dapat dibandingkan dengan keadaan sebelum diberi perlakuan (Nursalam, 2014).

Populasi adalah subjek (manusia) yang memenuhi kriteria yang telah ditetapkan. Populasi dalam penelitian ini adalah semua lansia yang tinggal di Rumah Pelayanan Sosial Lanjut Usia Wening Wardoyo Ungaran sebanyak 87 lansia dengan kisaran usia 60-90 tahun yang mengalami depresi ringan dan sedang.

Sampel terdiri atas bagian populasi terjangkau yang dapat dipergunakan sebagai subjek penelitian melalui sampling. Sampling adalah proses menyeleksi porsi dari populasi yang dapat mewakili populasi yang ada. Teknik pengambilan sampel dalam penelitian ini menggunakan total sampling. Total sampling adalah pengambilan sampel yang sama dengan jumlah populasi yang ada, dimana dalam penelitian ini sampel yang digunakan kurang dari 100 responden. Peneliti melakukan skrining sesuai kriteria inklusi dan eksklusi didapat 31 responden yang sesuai dengan kriteria penelitian dan digunakan semua (total sampling). criteria Inklusi Lansia yang mengalami depresi ringan dan sedang (kuesioner Geriatric Depression Scale(GDS), Lansia yang bersedia dan menandatangani informed consent (Sugiono, 2014).

Pada saat pengumpulan data pada penelitian ini, peneliti memperoleh surat pengantar izin penelitian kepada STIKES St. Elisabeth Semarang kepada Kepala Dinas Penanaman Modal dan Pelayanan Terpadu Satu Pintu (DPMPTSP) Provinsi Jawa Tengah, Dinas Sosial Provinsi Jawa Tengah, Kantor Kesatuan Bangsa Dan Politik Kabupaten Semarang, Kepala Panti Pelayanan Social Anak Wira Adhi 
Karya Ungaran. Peneliti mendapat surat pengantar izin penelitian dari STIKES St. Elisabeth Semarang Nomer 004.19/STUPEN S1/2019 tanggal 7 Januari 2019 kepada Kepala Dinas Penanaman Modal dan Pelayanan Terpadu Satu Pintu (DPMPTSP) Provinsi Jawa Tengah.Peneliti mendapat surat pengantar izin penelitian dari STIKES St. Elisabeth Semarang Nomer 004.18/STUPEN S1/2019 tanggal 7 Januari 2019 kepada Kepala Dinas Sosial Provinsi Jawa Tengah.Peneliti mendapat surat pengantar izin penelitian dari STIKES St. Elisabeth Semarang Nomer 004.16/STUPEN S1/2019 tanggal 7 Januari 2019 kepada Kepala Badan Kesatuan Bangsa dan Politik Kab Semarang.Peneliti mendapat surat pengantar izin penelitian dari STIKES St. Elisabeth Semarang Nomer 004.17/STUPEN S1/2019 tanggal 7 Januari 2019 kepada Kepala Rumah Pelayanan Sosial Lanjut Usia Wening Wardoyo.Peneliti mendapat surat rekomendasi penelitian dari Dinas Penanaman Modal dan Pelayanan Terpadu Satu Pintu nomer 070/12699/2019 tanggal 22 Januari 2019.Peneliti mendapat surat izin penelitian dari Dinas Sosial Nomer 071/113/I/2019 tangal 28 Januari 2019. Peneliti mendapat surat izin penelitian dari Kantor Kesatuan Bangsa dan Politik Nomer 070/208/I/2019 tanggal 22 Januari 2019. Peneliti melakukan studi pendahuluan untuk mengetahui jumlah lansia di Rumah Pelayanan Sosial Lanjut Usia Wening Wardoyo Ungaran pada tanggal 3 April 2019. Peneliti memilih 10 orang untuk menjadi numerator dengan kriteria numerator sebagai berikut: Mahasiswa S1 Ilmu Keperawatan yang sudah dinyatakan lulus dalam pelajaran dan praktek sistem komunitas Pembagian numerator; 5 orang pada pagi hari dan 5 orang pada sore hari. Numerator dapat berbahasa jawa.

Pada tanggal 23 Juli 2019 peneliti menjelaskan prosedur penelitian kepada numerator yang telah terpilih. Pada tanggal 24 Juli 2019 peneliti melakukan skrining untuk menentukan responden sesesuai dengan kriteria inklusi dan ekslusi yang telah ditentukan.

Pada tanggal 25 Juli 2019 peneliti menjelaskan aturan kegiatan kepada responden yang sudah memenuhi kriteria inklusi dan peneliti menjelaskan tujuan dan manfaat penelitian dan kemudian peneliti membagikan informed consent kepada responden dan membantu responden untuk mengisi informed consent tersebut. Pada tanggal 25 Juli 2019 pukul 07:00 WIB Peneliti melakukan pengukuran tingkat depresi dengan mengunakan kuesioner GDS sebelum diberikan terapi musik suara air mengalir dengan brainwave.

Pada tanggal 25 Juli samapi tanggal 27 Juli 2019 peneliti melakukan kegiatan penelitian selama 3 hari berturut-turut pada pagi hari pukul 06:30 WIB dan sore hari pukul 16:00 WIB. Adapun prosedur yang dilakukan yaitu: Peneliti atau numerator mendatangi masing-masing wisma, Peneliti atau numerator mempersiapkan alat-alat yang digunakan seperti; spiker, laptop, dan musik suara air mengalir dengan brainwave. Peneliti atau numerator mengumpulkan lansia yang sudah terpilih dan bersedia menjadi responden diruang tamu dan lansia dipersilahkan duduk melingkar dengan posisi senyaman mungkin. Sebelum memulai kegiatan peneliti atau numerator menjelaskan prosedur kegiatan dan aturan yang harus ditaati oleh lansia. Sebelum kegiatan dimulai lansia dipersilahkan untuk buang air kecil maupun buang air besar terlebih dahulu. Peneliti atau numerator memberikan terapi musik suara air mengalir dengan brainwave selama 15 menit tanpa jeda. Setelah 15 menit pemberian terapi, peneliti atau numerator mengucapkan terimakasih dan melakukan kontrak waktu untuk pemberian terapi 
musik kembali pada sore hari dan selanjutnya lansia dipersilahkan kembali melakukan kegiatan masing-masing.

Pada hari ke-3 tanggal 27 Juli 2019 pukul 16:20 WIB penelitian, peneliti melakukan pengukuran tingkat depresi dengan kuesioner GDS kembali setelah jeda 5 menit dari pemberian terapi musik pada sore hari.

Pengolahan data dalam penlitian ini menggunakan metode anatara lain: Scoring, tahapan ini dilakukan setelah ditetapkan kode jawaban atau hasil observasi, sehingga jawaban responden pada lembar kuesioner GDS dapat diberikan skor 0-4 normal, 5-8 depresi ringan, 9-11 depresi sedang, dan 12-15 depresi berat. Entry data, peneliti memasukan atau memindahkan data-data yang sudah didapatkan untuk dianalisis dengan menggunakan program komputerisasi. Editing adalah memeriksa kembali kebenaran data yang diperoleh ataudidapatkan oleh peneliti dari kegiatan pengumpulan data. Editingdilakukan pada tahap mengecek kelengkapan data.Sebelum melakukan analisa data, terlebih dahulu melakukan pengkode. Untuk jenis kelamin diberi kode 1 untuk laki-laki, 2 untuk perempuan. Untuk usia 1 untuk usia lanjut, 2 untuk usia lanjut tua. Untuk tingkat depresi 1 untuk normal, 2 untuk depresi ringan, 3 untuk depresi sedang, 4 untuk depresi berat.Tabulating adalah langkah memasukan data yang telah dikumpulkan peneliti kemudian diolah dengan bantuan program statistik yang ada di dalam program komputer. Mengelompokkan data kedalam suatu data tertentu terbentuk tabel maupun persentase. Peneliti melakukan pengecekan kembali setelah semua data dimasukan, untuk melihat kemungkinan adanya kesalahan, ketidaklengkapan data dan lainnya untuk dilakukan pembetulan dengan melihat distribusi frekuensi dari variabel yang diteliti (Buchari, 2015).

Analisis univariat bertujuan untuk menjelaskan karakteristik setiap variabel. Analisa univariat digunakan untuk mengidetifikasi setiap variabel yang diteliti secara terpisah dengan cara membuat tabel observasi tingkat depresi sebelum dan sesudah diberikan perlakuan dan menganalisis karateristik menurut usia dan jenis kelamin. Analisa bivariat adalah analisa yang digunakan untuk menguji ada atau tidaknya pengaruh antara variabel indevenden dan variabel dependen. Variabel dependen didalam penelitian ini adalah data kategorik sehingga, Data yang didapat dari 31 responden dimasukkan kedalam program komputerisasi untuk diuji bivariat menggunakan uji Marginal Homogeneity. Hasil uji Marginal homogeneity didapatkan hasil $p$ value 0.003 yang artinya $p<0.05$ (Sopiyudin, 2011).

\section{HASIL DAN PEMBAHASAN}

\section{HASIL PENELITIAN}

\section{Analisa Univariat}

Tabel 1

Responden Berdasarkan Usia Di Rumah Pelayanan Sosial Lanjut Usia Wening Wardoyo Ungaran Tahun 2019 (n=31)

\begin{tabular}{lcc}
\hline \multirow{2}{*}{ Usia } & Responden & \\
\cline { 2 - 3 } & $\mathrm{n}$ & Persentase (\%) \\
\hline Lanjut usia (60-74) & 15 & 48.4 \\
Lanjut usia tua (75-90) & 16 & 51.6 \\
\hline
\end{tabular}


Bali Medika Jurnal.

Vol 7 No 1, 2020: 125-137

ISSN : 2615-7047

DOI: https://doi.org/10.36376/bmj.v7i1

\begin{tabular}{lcc}
\hline Total & 31 & 100.0 \\
\hline
\end{tabular}

Responden terbanyak dalam penelitian ini adalah Lansia Tua sebanyak 16 responden (51.6\%) dan usia Lansia yaitu 15 responden (48.4\%).

Tabel 2

Responden Berdasarkan Jenis Kelamin Di Rumah Pelayanan Sosial Lanjut Usia Wening Wardoyo Ungaran Tahun $2019(\mathrm{n}=31)$

\begin{tabular}{lcc}
\hline \multirow{2}{*}{ Jenis Kelamin } & Responden & \\
\cline { 2 - 3 } & $\mathrm{n}$ & Persentase $(\%)$ \\
\hline Laki-laki & 12 & 38.7 \\
Perempuan & 19 & 61.3 \\
\hline Total & 31 & 100.0 \\
\hline
\end{tabular}

Responden terbanyak dalam penelitian ini adalah responden dengan jenis kelamin perempuan sebanyak 19 responden $(61.3 \%)$ dan responden dengan jenis kelamin laki-laki sebanyak 12 responden (38.7\%).

Tabel 3

Responden Berdasarkan Tingkat Depresi Lansia sebelum diberi musik suara air mengalir dengan brainwave Di Rumah Pelayanan Sosial Lanjut Usia Wening Wardoyo Ungaran Tahun $2019(\mathrm{n}=31)$

\begin{tabular}{|c|c|c|}
\hline \multirow{2}{*}{$\begin{array}{c}\text { Tingkat Depresi sebelum } \\
\text { Terapi }\end{array}$} & \multicolumn{2}{|l|}{ Responden } \\
\hline & $\mathrm{n}$ & Persentase (\%) \\
\hline Ringan & 27 & 87.1 \\
\hline Sedang & 4 & 12.9 \\
\hline Total & 31 & 100.0 \\
\hline
\end{tabular}

Responden yang mengalami depresi ringan sebelum pemberian terapi musik suara air mengalir dengan brainwave sebanyak 27 responden $(87.1 \%)$ dan responden yang mengalami depresi sedang sebelum pemberian terpi musik suara air mengalir dengan brainwave sebanyak 4 responden (12.9\%).

Tabel 4

Responden Berdasarkan Tingkat Depresi Lansia setelah diberi Musik Suara Air Mengalir dengan brainwave Di Rumah Pelayanan Sosial Lanjut Usia Wening Wardoyo Ungaran Tahun $2019(\mathrm{n}=31)$

\begin{tabular}{|c|c|c|}
\hline \multirow{2}{*}{$\begin{array}{c}\text { Tingkat Depresi setelah } \\
\text { Terapi }\end{array}$} & \multicolumn{2}{|c|}{ Responden } \\
\hline & $\mathrm{n}$ & Persentase $(\%)$ \\
\hline Normal & 7 & 22.6 \\
\hline Ringan & 22 & 71.0 \\
\hline Sedang & 2 & 6.5 \\
\hline Total & 31 & 100.0 \\
\hline
\end{tabular}


Bali Medika Jurnal.

Vol 7 No 1, 2020: 125-137

ISSN : 2615-7047

DOI: https://doi.org/10.36376/bmj.v7i1

Responden yang mengalami tingkat depresi paling banyak setelah pemberian terapi musik suara air mengalir dengan brainwave yaitu responden yang mengalami depresi ringan sebanyak 22 responden $(71.0 \%)$, responden yang mengalami depresi normal setelah pemberian terapi musik suara air mengalir dengan brainwave sebanyak 7 responden (22.6\%), dan responden yang mengalami depresi sedang setelah pemberian terpi musik suara air mengalir dengan brainwave sebanyak 2 responden $(6.5 \%)$.

\section{Tabel 5}

Responden Berdasarkan nilai Rata-rata tingkat Depresi Lansia sebelum dan setelah diberi Musik Suara Air Mengalir dengan brainwave Di Rumah Pelayanan Sosial Lanjut Usia Wening Wardoyo Ungaran Tahun 2019 (n=31)

\begin{tabular}{lccc}
\hline $\begin{array}{l}\text { Tingkat } \\
\text { Depresi }\end{array}$ & Nilai Minimal & Nilai Maksimal & $\begin{array}{c}\text { Nilai Rata- } \\
\text { rata }\end{array}$ \\
\hline Pre Test & 5 & 11 & 6.32 \\
Post Test & 4 & 11 & 5.84 \\
\hline
\end{tabular}

Nilai tingkat depresi sebelum diberi terapi musik suara air mengalir dengan brainwave yang memiliki nilai maksimal adalah 11 dan yang memiliki nilai minimal adalah 5, dengan nilai rata-rata 6.32. Nilai tingkat depresi sesudah diberi terapi musik suara air mengalir dengan brainwave yang memiliki nilai maksimal adalah 11 dan yang memiliki nilai minimal adalah 4, dengan nilai rata-rata 5.84.

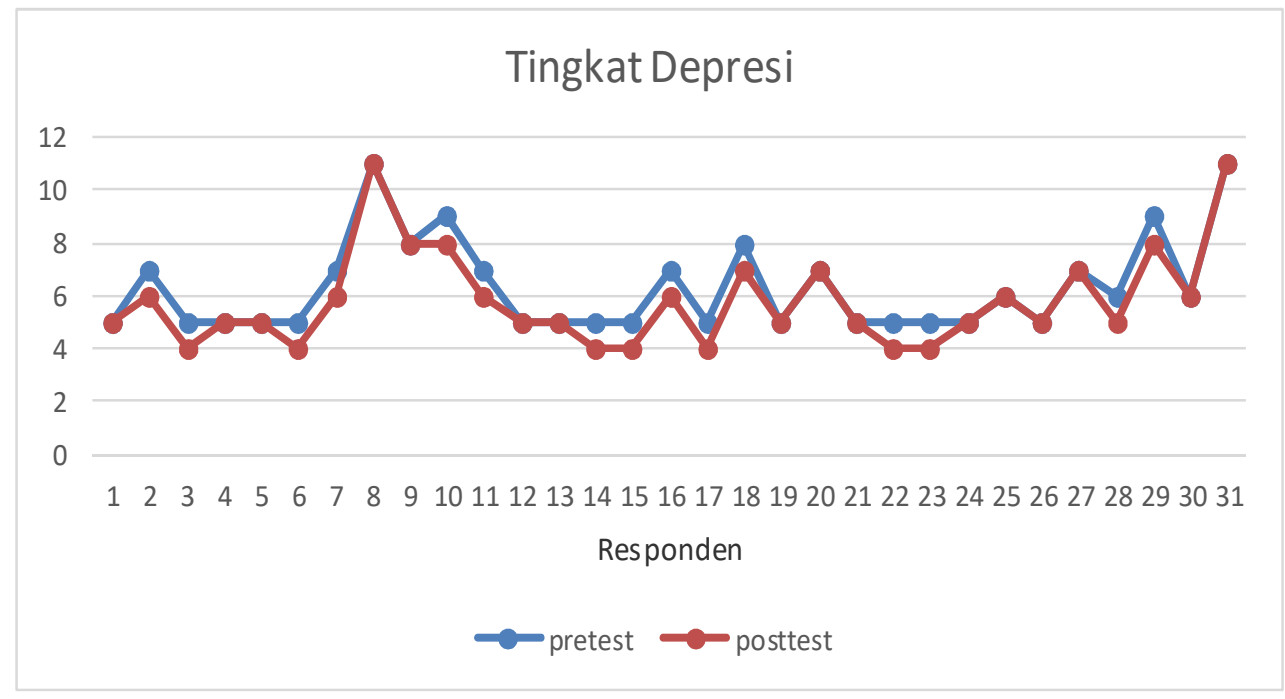

Gambar 1. Responden Berdasarkan Tingkat Depresi Lansia sebelum dan setelah diberi Musik Suara Air Mengalir dengan Brainwave Di Rumah Pelayanan Sosial Lanjut Usia Wening Wardoyo Ungaran Tahun 2019 ( $\mathrm{n}=31$ ) Menunjukkan bahwa tingkat depresi sebelum diberi terapi musik suara air mengalir dengan brainwave tingkat depresi terendah 5 dan tingkat depresi tertinggi 11. Tingkat depresi setelah diberi terapi musik suara air mengalir dengan brainwave didapatkan tingkat depresi terendah 4 dan tingkat depresi tertinggi 11. 
Bali Medika Jurnal.

Vol 7 No 1, 2020: 125-137

ISSN : 2615-7047

DOI: https://doi.org/10.36376/bmj.v7i1

\section{Analisa Bivariat}

Tabel 6

Pengaruh Terapi Musik Suara Air Mengalir dengan Brainwave terhadap Penurunan Tingkat Depresi pada Lansia di Rumah Pelayanan Sosial Lanjut Usia Wening Wardoyo Ungaran 2019. $(\mathrm{n}=31)$

\begin{tabular}{|c|c|c|c|c|c|c|c|c|c|}
\hline \multirow{3}{*}{$\begin{array}{l}\text { Klasifikasi } \\
\text { depresi } \\
\text { sebelum } \\
\text { perlakuan }\end{array}$} & \multicolumn{6}{|c|}{ Klasifikasi depresi setelah perlakuan } & & & \multirow{3}{*}{$\begin{array}{c}P \\
\text { value }\end{array}$} \\
\hline & \multicolumn{2}{|c|}{ Normal } & \multicolumn{2}{|c|}{$\begin{array}{c}\text { Depresi } \\
\text { ringan }\end{array}$} & \multicolumn{2}{|c|}{$\begin{array}{l}\text { Depresi } \\
\text { sedang }\end{array}$} & \multicolumn{2}{|c|}{ Total } & \\
\hline & $\mathrm{n}$ & $\%$ & $\mathrm{n}$ & $\%$ & $\mathrm{n}$ & $\%$ & $\mathrm{~N}$ & $\%$ & \\
\hline $\begin{array}{l}\text { Depresi } \\
\text { ringan }\end{array}$ & 7 & 22.6 & 20 & 64.5 & 0 & 0 & 27 & 87.1 & \\
\hline $\begin{array}{l}\text { Depersi } \\
\text { sedang }\end{array}$ & 0 & 0 & 2 & 6.5 & 2 & 6.5 & 4 & 12.9 & 0.003 \\
\hline Total & 7 & 22.6 & 22 & 71.0 & 2 & 6.5 & 31 & 100 & \\
\hline
\end{tabular}

Hasil analisis diatas bahwa nilai significan dari uji Marginal Homogeneity yaitu $p$ value 0,003 yang artinya $p<0,05$ sehingga $\mathrm{H} 0$ ditolak $\mathrm{H} 1$ diterima yang artinya ada pengaruh pemberian Terapi Musik Suara Air Mengalir dengan Brainwave terhadap Penurunan Tingkat Depresi pada Lansia di Rumah Pelayanan Sosial Lanjut Usia Wening Wardoyo Ungaran.

\section{PEMBAHASAN}

Persamaan antara peneliti dengan peneliti sebelumnya yang dilakukan oleh Widyasih Sunaringtyas dimana penelitian ini sama-sama menggunakan musik suara alam air mengalir dengan brainwave dan sama menggunakan responden lansia. Penelitian yang sama dilakukan oleh Wijayanti et al. (2016) yang juga menggunakan suara alam. Kesimpulan kedua penelitian terdahulu menggunakan terapi musik suara alam untuk penatalaksanaan kasus gangguan psikologis.

Perbedaan antara peneliti dengan peneliti sebelumnya yang dilakukan oleh Widyasih Sunaringtyas dimana penelitian ini dilakukan pada tingkat insomnia lansia. Penelitian berikutnya dilakukan oleh Kurnia Wijayanti dimana peneliti mengunakan responden pasien kritis, peneliti ini meneliti tingkat kecemasan responden menggunakan Visual Analog Scale-anxiety (VAS-A) dan suara alam yang digunakan dalam penelitian ini adalah suara burung dengan kombinasi. Perbedaan dalam penelitian ini adalah peneliti ingin melihat pengaruh pemberian musik suara air mengalir dengan brainwave terhadap tingkat depresi pada lansia. Penelitian ini menggunakan kuesioner Skala Depresi Geriatri (GDS).

Lansia tua sering terjadi penurunan kondisi fisik atau biologis, kondisi psikologis, serta perubahan kondisi sosial dan ekonomi. Sehingga perubahan ini akan memberikan pengaruh pada seluruh aspek kehidupan termasuk kesehatan. Seiring proses penuaan lansia tua sering mengalami berbagai macam gangguan perasaan seperti sedih, cemas, kesepian dan mudah tersinggung, sehingga pada lansia tua stress lingkungan sering menyebabkan depresi dan kemampuan beradaptasi sudah menurun (Fatma et al., 2018; Hadi \& Kris, 2009).

Penelitian Gambaran Tingkat Depresi Lansia yang Melakukan Senam di panti Sosial Tresna Werdha di Jakarta, menunjukkan bahwa Lansia berusia 60-74 tahun memiliki tingkat melakukan aktivitas fisik yang lebih baik dibandingkan dengan 
lansia yang dalam kategori lainnya sehingga semakin bertambah usia maka keaktifan melakukan aktivitas fisik pun menurun. Sehingga berdasarkan usia, menunjukkan bahwa mayoritas lansia kategori lanjut usia (60-74 tahun) tidak mengalami depresi sedangkan lansia kategori lanjut usia tua (75-90 tahun) cenderung banyak mengalami depresi ringan. Memasuki masa lansia terjadi berbagai perubahan fisiologis dan psikososial yang dapat menjadi stresor bagi lansia. Seiring peningkatan usia, lansia memiliki peningkatan risiko depresi (Putri \& Fitriyani, 2016).

Penelitian Pengaruh Terapi Musik Klasik terhadap Tingkat Depresi pada Lansia di Unit Rehabilitasi Sosial Wening Wardoyo Kecamatan Ungaran Kabupaten Semarang menunjukkan bahwa depresi menyerang 10-15\% lansia 65 tahun keatas yang tinggal dikeluarga dan angka depresi meningkat secara drastis pada lansia yang tinggal di institusi, dengan sekitar $50-75 \%$ penghuni perawatan jangka panjang memiliki gejala depresi ringan sampai sedang (Marzuki \& Lestari, 2018).

Perempuan lebih sering mengalami depresi dikarenakan adanya perubahan hormon serotonin yang naik turun yang dapat memicu terjadi gejala depresi. Selain itu faktor lingkungan terutama terkait peran perempuan sebagai ibu, istri, dan anak bagi orang tuanya, dimana perempuan harus berupaya menyeimbangkan ketiga peran tersebut sehingga tidak jarang membuat perempuan rentang mengalami stress kronis yang dapat memicu terjadi depresi (Novi, 2018).

Usia harapan hidup perempuan lebih tinggi daripada laki-laki, hal ini terlihat dengan keberadaan penduduk lansia perempuan yang lebih banyak dari pada lansia laki-laki. Hal ini dikarenakan jika wanita stress bisa tersalurkan dengan cara menangis, berkeluh kesah dan sebagainya, sedangkan lelaki pantang menangis, pantang berkeluh kesah sehingga pada saat stress sistem hormon menghantam organ-organ didalam tubuh nya (Kemenkes RI, 2014; Prasetya, 2009).

Alasan wanita lebih betah tinggal dipanti dan hidup sendiri tanpa menikah lagi adalah keengganannya untuk beradaptasi kembali dengan kehidupan pernikahan yang baru. Setelah menjanda bertahun-tahun, ada rasa malas untuk berkenalan dan memulai segalanya lagi dari nol. Terlebih lagi apabila sang perempuan sukses meniti karier dan tidak memiliki persoalan dalam mengurus anak (Yayuk, 2017).

Penelitian ini memberikan terapi musik suara air mengalir dengan brainwave terhadap penurunan tingkat depresi lansia di Rumah Pelayanan Sosial Lanjut Usia Wening Wardoyo Ungaran, dimana didapatkan banyak lansia wanita yang mengalami depresi. Ada beberapa penelitian yang menyatakan bahwa wanita berisiko lebih tinggi mengalami depresi dibandingkan laki-laki, sehingga pernyataan ini selaras dengan hasil penelitan yang dilakukan di Rumah Pelayanan Sosial Lanjut Usia Wening Wardoyo Ungaran mengenai terapi musik suara air mengalir dengan barainwave terhadap tingkat depresi pada lansia.

Peneliti mendapatkan data responden dari tidak mengalami penurunan, disebabkan karena dari observasi peneliti ada beberapa faktor yang membuat responden kurang menikmati terapi musik suara air mengalir dimana responden terlihat jenuh dan kurang menikmati terapi musik yang diberikan selama 3 hari berturut-turut dan responden lebih sering mengobrol dengan sesama temannya sambil mendengarkan musik suara air mengalir, sehingga hasil tingkat depresi setelah pemberian terapi musik suara air mengalir terjadi penurunan satu angka saja dan ada yang tidak mengalami perubahan tingkat depresi. 
Responden yang mengalami depresi sedang sebelum pemberian terpi musik suara air mengalir dengan brainwave, hasilnya masih mengalami tingkat depresi sedang, hal ini disebabkan oleh karena responden acuh tak acuh saat diberikan intervensi, sebagian responden juga merasa bosan karena diberikan intervensi secara berulang-ulang selama 3 hari. Derdasarkan teori dari Budi mengatakan bahwa salah satu faktor eksternal yang menyebabkan lansia mengalami depresi adalah rasa bermusuhan, kemarahan, kekecewaan yang ditujukan pada suatu objek atau pada diri sendiri, sehingga lansia tersebut akan meninggalkan minat mereka untuk melakukan kegiatan sehari-hari.

Data yang didapat dianalisis menggunakan uji Marginal Homogeneity dimana hasil analisis data memiliki nilai signifikan dari uji Marginal Homogeneity yaitu $p$ value 0,003 yang artinya $p<0,05$ sehingga $\mathrm{H} 0$ ditolak $\mathrm{H} 1$ diterima yang artinya ada pengaruh Terapi Musik Suara Air Mengalir dengan Brainwave terhadap Penurunan Tingkat Depresi pada Lansia di Rumah Pelayanan Sosial Lanjut Usia Wening Wardoyo Ungaran.

Hasil penelitian ini selaras dengan teori yang menyatakan bahwa Terapi musik termasuk dalam binaural beat yang akan meransang pusat saraf (otak) tepatnya pada belahan otak kanan, dimana musik ini memiliki nuansa yang sejuk dan lembut. Frekuensi ini berisi pesan-pesan subliminal (pesan yang hanya bisa didengar oleh otak bawah sadar), dimana saat sel otak berdengung dalam frekuensi gelombang tetha. Gelombang theta juga bisa menyebabkan munculnya daya imajinasi sehingga dapat menciptakan sesuatu hal yang seru dan mengasikkan. Fase gelombang theta juga dapat muncul ketika seseorang memiliki perasan dekat dengan Tuhan, sehingga dengan menstimulasi otak agar berada pada fase gelombang theta bisa menciptakan ketenangan jiwa (Marzuki \& Lestari, 2018).

Saat dilakukan terapi musik suara alam, implus yang didengar akan dihantarkan oleh saraf aferen yang mengatur fungsi pendengaran ke otak bawah sadar untuk mengubah gelombang otak menjadi gelombang otak alfa dimana gelombang otak alfa akan menyebabkan peningkatan serotonin, diamana Serotonin adalah suatu neurotransmitter yang bertanggung jawab terhadap peristiwa lapar dan perubahan mood. Serotonin dalam tubuh kemudian diubah menjadi hormon melatonin yang memiliki efek regulasi terhadap relaksasi tubuh yang pada akhirnya depresi yang dirasakan oleh responden dapat menurun sebagai akibat dari perubahan mood (Arif, 2009; Lestari et al., 2009).

Penelitian Pengaruh Terapi Musik terhadap Tingkat Depresi pada Lansia menunjukan bahwa ada pengaruh pemberian terapi musik terhadap tingkat depresi lansia, dimana musik memberi dampak dari psikologis lansia. Psikologis lansia sebelum dan setelah dilakukannya terapi musik sangatlah berbeda dimana lansia sebelum diberikan terapi musik akan merasakan gelisah, murung, dan tidak berminat untuk melakukan aktivitas sedangakn setelah dilakukannya terapi musik maka lansia merasa ketenagan secara emosional sehingga lansia mampu mengontrol diri seperti cemas berlebihan, khawatir, sedih yang menyebabkan psikologis lensia tersebut menjadi tenang (Rahma et al., 2017).

Hasil penelitian ini memiliki kesamaan dengan penelitian sebelum nya yang memiliki pengaruh antar terapi musik terhadap depresi. Dimana terapi musik bekerja dengan memberi rangsangan suara yang terdiri dari melodi, ritme, harmoni, timbre, bentuk dan gaya yang diorganisir sedemikian rupa hingga tercipta musik yang bermanfaat untuk kesehatan fisik dan mental (Dayat, 2018). 


\section{SIMPULAN DAN SARAN}

Analisis hasil menunjukkan nilai siknifikan dari uji Marginal Homogeneity $p$ value 0,003 $(p<0,05)$, artinya ada Pengaruh Terapi Musik Suara Air Mengalir dengan Brainwave terhadap Penurunan Tingkat Depresi pada Lansia di Rumah Pelayanan Sosial Lanjut Usia Wening Wardoyo Ungaran.

Hasil penelitian ini dapat menambah pengetahuan untuk merawat lansia yang mengalami depresi dengan terapi non farmakologi, dengan cara pemberian terapi musik suara air mengalir dengan brainwave. Penelitian ini daapt memberikan gambaran tentang terapi musik suara air mengalir dengan brainwave sebagai tindakan mandiri untuk menurunkan depresi pada lansia.

\section{UCAPAN TERIMA KASIH}

Peneliti mengucapkan banyak terimaksih kepada pihak - pihak yang terlibat dalam proses penelitian ini, Ketua STIKes St. Elisabeth Semarang, Pimpinan Rumah Pelayanan Sosial Lanjut Usia Wening Wardoyo Ungaran, numerator yang telah membantu terlaksananya penelitian ini.

\section{DAFTAR PUSTAKA}

Arif, M. (2009). Pengantar Asuhan Keperawatan Klien dengan Gangguan Sistem Persyarafan. Salemba Medika.

Buchari, L. (2015). Metodologi Penelitian Kebidanan: Panduan Penulisan Protokol Laporan Hasil Penelitian. Yayasan Pustaka Obor Indonesia.

Dayat, S. (2018). Terapi Musik. Dayat Suryana Independent.

Dirgayunita, A. (2016). Depresi: Ciri, penyebab dan penangannya. Journal AnNafs: Kajian Penelitian Psikologi, 1(1), 1-14. http://ejournal.iaitribakti.ac.id/index.php/psikologi/article/download

Fatma, E. S. M., Riasmini, N. M., \& Hartini, T. (2018). Meningkatkan Kualitas Hidup Lansia Konsep dan Berbagai Intervensi. Wineka Media.

Hadi, M., \& Kris, P. (2009). Buku Ajar Boedhi-Darmojo Geriatri (Ilmu Kesehatan Lansia). Balai Penerbit FKUI.

Keliat, B. A., Wiyono, A. P., \& Susanti, H. (2011). Manajemen Kasus Gangguan Jiwa. EGC.

Kemenkes RI. (2014). Situasi dan Analisis Lanjut Usia.

Kemenkes RI. (2017). Analis Lansia di Indonesia. Kementerian Kesehatan Republik Indonesia. www.depkes.go.id/

Lestari, R., Setyohadi, S., \& Kumboyono, K. (2009). Pengaruh Irama Musik Tradisional Jawa Terhadap Penurunan Skor Depresi pada Lanjut Usia. Jurnal Ilmu Keperawatan, 4(3), 141-145. https://media.neliti.com/media/publications-ID-pengaruh-irama-musiktradisional-jawa-te.pdf

Maryam, S., \& Fatma, E. S. M. (2008). Mengenal Usia Lanjut dan Perawatannya. Salemba Medika.

Marzuki, M. B., \& Lestari, P. (2018). Pengaruh Terapi Musik Klasik Terhadap 
Bali Medika Jurnal.

Vol 7 No 1, 2020: 125-137

ISSN : 2615-7047

DOI: https://doi.org/10.36376/bmj.v7i1

Tingkat Depresi Pada Lansia Di Unit Rehabilitasi Sosial Wening Wardoyo Kecamatan Ungaran Kabupaten Semarang. Jurnal Keperawatan Komunitas, $\quad$ 2(2), 81-86. https://jurnal.unimus.ac.id/index.php/JKK/article/view

Namora, L. L. (2009). Depresi Tinjauan Psikologis. Kencana.

Novi, S. (2018). Wanita Dua Kali Lebih Berisiko Kena Depresi daripada Pria. Hello Sehat. https://www.google.co.id/amp/s/hellosehat.com/hidupsehat/psikologi/depresi-pada-wanita-lebih-berisiko/amp

Nursalam. (2014). Metodologi Penelitian Ilmu Keperawatan Pendekatan Praktis (3rd ed.). Salemba Medika.

Prasetya. (2009). Harapan Hidup Wanita Lebih Tinggi Dibanding Laki-laki. Prasetya Universitas Brawijaya. https://prasetya.ub.ac.id/berita/HarapanHidup-Wanita-Lebih-tinggi-Dibanding-laki-laki-id.pdf

Putri, S. I., \& Fitriyani, P. (2016). Gambaran Tingkat Depresi Lansia yang Melakukan Senam Di Panti Sosial Tresna Werdha di Jakarta. Jurnal Keperawatan Indonesia, 19(2), 92-99. https://media.neliti.com/media/publications-gambaran-tingkat-depresilansia-yang-mel.pdf

Rahma, P. E., Sulastri, S., \& Rohayati, R. (2017). Pengaruh Terapi Musik terhadap Tingkat Depresi pada Lansia. Jurnal Ilmiah Keperawatan Sai Betik, 9(2), 151-157.

Sopiyudin, D. (2011). Statistik untuk Kedokteran dan Kesehatan: Deskriptif, Bivariat, dan Multivariat dilengkapi Aplikasi dengan mengunakan SPSS. Alfabeta.

Sugiono. (2014). Metode Penelitian Manajemen. Alfabeta.

WHO. (2017). Depression and Other Common Mental Disorders. http://apps.who.int/iris/bitstream/handle/WHO_MSD_MER.2017.2_eng.p df/

Wijayanti, K., Johan, A., Rochana, N., \& Anggorowati, C. S. (2016). Musik suara alam terhadap penurunan kecemasan pada pasien kritis. Jurnal Keperawatan Dan Pemikiran Ilmiah, 2(3), 1-10.

Yayuk, W. (2017). Alasan Perempuan Memilih Menjanda dan Malas Menikah Lagi. Tempo. Tempo.co 